\title{
Comparison of the behavior of motorists in traffic safety in Yogyakarta Special Region by gender
}

\author{
Poei Purnamasari ${ }^{1}$, and Dwijoko Ansusanto ${ }^{1}$ \\ ${ }^{1}$ Civil Engineering Department, Atma Jaya Yogyakarta University, Yogyakarta, Indonesia
}

\begin{abstract}
Yogyakarta as a student city, a cultural city and tourist destination after Bali changing rapidly year after year. In the 70 s, transportation mode in this small town were bicycles, tricycles, buggy and only few motor vehicles. Because of the development of the technology and the number of newcomers grew larger, Yogyakarta is now dominated by two-wheeled motor vehicles and cars. That facts resulted the higher risk of danger, if the riders are not well behaved and disregard the safety instructions on the road. Therefore this study had been conducted in Yogyakarta Special Region (DIY) with the objection to compare and observe the behavior of the road users based on the gender. The study used explanatory research with the reference to the Law of the Republic of Indonesia No. 22 of 2009 about the safety instructions for the riders on the road, with common people, high school and university students as the respondents.
\end{abstract}

\section{Introduction}

Yogyakarta as a student city, a cultural city and tourist destinations after Bali changing rapidly year after year. Almost $20 \%$ of the productive population in Yogyakarta are students. Many young people from Sabang to Merauke are studying in this small city, which covers only $0.017 \%$ of the land area of Indonesia. In the 70 s, transportation mode in this small town were bicycles, tricycles, buggy and only few motor vehicles. The growth of the number of newcomers in town (either permanently or temporarily) as well as the development of the technology that made the vehicle go faster than the previous mode, causing the domination of two-wheeled motor vehicles and cars in Yogyakarta. With the need of easier and faster mobility as the main reason, having a motor vehicle nowadays seems to have become a necessity. It is easier than before, because there are motorcycles, that relatively affordable for everyone. Using only 500,000.00 rupiah as a down payment, anybody can take a new motorcycle home. Consequently, the number of vehicles in Yogyakarta is now dominated by two-wheeled motor vehicles and cars. As a dynamic city, Yogyakarta has a fast pace change that is also affecting road users to be eager to move sooner to the destination, hence the traffic become more chaotic. In this case, riders without ethical behavior and disregard for safety on the road would endanger the safety of both fellow motorists, pedestrians and other road users. Factors such as gender, age, educational background and physical condition, cognitive and psychomotor and knowledge in the traffic the factors can influence the behavior of the riders. In reference to the Law of the Republic of Indonesia No. 22 of 2009 [1], article 106 paragraph (2): every person who 
drives a motor vehicle on the road shall prioritize the safety of pedestrians and cyclist $\mathrm{s}$. Article 284 consist of : Any person driving a motor vehicle without priority to pedestrian or cyclists safety as referred to in Article 106 paragraph (2) shall be imprisoned for a maximum of two months or a fine of not more than Rp 500,000.00 (five hundred thousand rupiahs) Article 131 paragraph (1): Pedestrians are entitled to the availability of supporting facilities in the form of sidewalks, crossings and other facilities. (2) Pedestrians are entitled to priority when crossing the road at the crossing. (3) In the absence of facilities as referred to in paragraph (1) Pedestrians shall have the right to cross in the chosen place with due regard to their safety.

\section{Subjects and Methodology}

Heinrich [2] said that there exists an important distinction between overt and covert behaviour. Only overt behaviour can be observed and recorded. Covert behaviour is never open to direct observation, it can only be deduced from external behaviour. By covert behaviour we mean cognition, emotions, and the building up of attitudes or habits. This covert behaviour is usually considered to be the logical, temporal and structural precondition for overt behaviour, and for this reason it seems logical to direct attempts at modifying behaviour to the covert level. Heinrich [2] also mentioned that In the feeling of responsibility and in efforts to make road traffic safer it is frequently the first-mentioned meaning of the term change which dominates: we have to make people behave more safely and then traffic in general will become safer! But education which ignores the fact that the influence of situational factors on the behaviour of people may be just as strong as that of dispositional factors, is doomed to failure. data also came from the first year of Competitive grant research [4] this study was conducted in Yogyakarta Special Region (DIY), which consists of 4 districts and 1 city (Sleman; Bantul; Kulonprogo; Gunungkidul and city of Yogyakarta). There are total 1010 Questionnaire with high school students, university students and common people as the respondents. The comparison of the motorists' behavior based on gender in traffic safety in Yogyakarta Special Region from each districts would be conducted using explanatory research. Like in Fishbein [3], the question types in the questionnaire using Likert scale related to attitudes and behavior of road users are shown in the Table 1 below.

Table 1. Questions related to attitudes and behavior of road users.

\begin{tabular}{|c|c|c|}
\hline $\begin{array}{c}\mathrm{N} \\
\mathrm{O}\end{array}$ & Code & Questions \\
\hline 1 & DF1 & Road users are obligated to comply with traffic signs / road markings \\
\hline 2 & DF2 & $\begin{array}{l}\text { Pedestrians crossing on the zebra-crossinging are protected by the } \\
\text { Traffic Act }\end{array}$ \\
\hline 3 & DF3 & All road users must respect and prioritize road crossers \\
\hline 4 & DF4 & Zebra-crossinging makes it easy for pedestrians to cross the road \\
\hline 5 & DF5 & $\begin{array}{l}\text { I feel safer when I cross in zebra Crossing, that's why I always cross } \\
\text { the road using it. }\end{array}$ \\
\hline 6 & DF6 & Crossing on the zebra Crossing guarantees the safety of the crossers \\
\hline 7 & DF7 & $\begin{array}{l}\text { Drivers should slowing down their speed as they approach the zebra } \\
\text { Crossing }\end{array}$ \\
\hline 8 & DF8 & Zebra Crossing users are appreciated by Drivers in DIY \\
\hline 9 & DF9 & $\begin{array}{l}\text { It is difficult to cross the street without the officer's help, even though } \\
\text { it's in zebra Crossing. }\end{array}$ \\
\hline 10 & DF10 & Pedestrians feel free to cross anywhere along the way \\
\hline 11 & DF11 & When I need to cross the street and the zebra Crossing is far away from \\
\hline 12 & DF12 & There are differences in difficulty level between crossing in zebra- \\
\hline 13 & DF13 & In my opinion, many of the traffic signs in DIY blocked by trees / pole \\
\hline
\end{tabular}




\begin{tabular}{|c|c|c|}
\hline 14 & DF14 & the intersection even though the traffic lights are \\
\hline 15 & DF15 & I always carry a complete driving documents when I drive car / motor \\
\hline 16 & DF16 & I always overtaking another vehicle either from the left or right side. \\
\hline 17 & DF17 & I overtaking another vehicle either from the left or right side. \\
\hline 18 & DF18 & When I want to turn or change lanes, I always turn on the turn signal \\
\hline 19 & DF19 & While waiting for the train to passed the train crossing. I always stav at \\
\hline 20 & DF20 & After I turned or moved to another lane, I always turn off the turn light \\
\hline 21 & DF21 & I always check the condition of the vehicle such as wind pressure, \\
\hline 22 & DF22 & In my opinion, many of the traffic lights in DIY blocked by trees / pole \\
\hline 23 & DF23 & When driving I alwavs be aggressive and do not want to lose if passed \\
\hline 24 & DF24 & I always receive / call / see / send SMS while driving on the highway. \\
\hline 25 & DF25 & I will quickly replace the brake lining before it's worn out \\
\hline 26 & DF26 & Dysfunction brakes light will always be replaced quickly \\
\hline 27 & DF27 & I don't use a helmet if I drive in a short distance (about $1 \mathrm{~km}$ ) \\
\hline 28 & DF28 & I always pay attention to the safety of the people around whil \\
\hline 29 & DF29 & of the red light is on and \\
\hline 30 & DF30 & I could be distracted by the sound surround me (for ex \\
\hline 31 & DF31 & I always look around and give a sign when I want to overtake / turn / \\
\hline 32 & DF32 & e while driving 0 \\
\hline 33 & DF33 & le I cared for. \\
\hline 34 & DF34 & $\mathrm{n}$ DIY is \\
\hline 35 & DF35 & In my opinion, the implementation of sanctions against traffic violators \\
\hline 36 & DF36 & I immediately stop the vehicle when the red light is almost on \\
\hline 37 & DF37 & During bad weather / rain / misty / smokv, I reduce the speed of the \\
\hline 38 & DF38 & I always use a helmet while driving motorcycle \\
\hline 39 & DF39 & ss the street marking/ move to another lane when I \\
\hline 40 & DF40 & I will leap over to another lane/track in uphill road \\
\hline 41 & DF41 & In my opinion, the number of traffic signs in DIY is sufficient \\
\hline 42 & DF42 & \\
\hline 43 & DF43 & $t$ for another vehicle before I op \\
\hline 44 & DF44 & When I pull the brakes, I will alway \\
\hline 45 & DF45 & \\
\hline
\end{tabular}

\section{Analysis}

From all of the 45 questions above can be divided into 5 groups of respondents' opinions: 1) about signs in DIY, 2) about traffic signaling tools (APILL), 3) about the completeness of driving documents, 4) attitudes and behavior of respondents about zebra Crossing, 5) the behavior of respondents while driving.

\subsection{About signs in DIY}

From Table 2. and Table 3., it appears that female and male respondents in 4 districts and 1 city have the same opinion in terms of priority sequences related to signs. They prioritize DF1 "Road users are obligated to comply with traffic signs / road markings" and assume DF13 "In my opinion, many of the traffic signs in DIY are blocked by trees / pole / banners/ not located in the appropriate location" less important.

Table 2. Female respondents opinion about signs in DIY

\begin{tabular}{|c|c|c|c|c|c|c|c|c|c|}
\hline \multicolumn{2}{|c|}{ Bantul } & \multicolumn{2}{c|}{ Gunungkidul } & \multicolumn{2}{c|}{ Kulonprogo } & \multicolumn{2}{c|}{ Sleman } & \multicolumn{2}{c|}{ Yogyakarta } \\
\hline Code & $\begin{array}{c}\text { Mean } \\
(\mathrm{F})\end{array}$ & Code & $\begin{array}{c}\text { Mean } \\
(\mathrm{F})\end{array}$ & Code & $\begin{array}{c}\text { Mean } \\
(\mathrm{F})\end{array}$ & Code & $\begin{array}{c}\text { Mean } \\
(\mathrm{F})\end{array}$ & $\begin{array}{c}\text { Code } \\
(\mathrm{F})\end{array}$ \\
\hline DF1 & 3,66 & DF1 & 3,69 & DF1 & 3,67 & DF1 & 3,74 & DF1 & 3,76 \\
\hline DF41 & 2,73 & DF41 & 2,66 & DF41 & 2,64 & DF41 & 2,64 & DF41 & 3,07 \\
\hline
\end{tabular}




\begin{tabular}{|l|c|c|c|c|c|c|c|c|c|}
\hline DF13 & 1,97 & DF13 & 2,10 & DF13 & 1,95 & DF13 & 2,03 & DF13 & 1,99 \\
\hline
\end{tabular}

Table 3. Male respondents opinion about signs in DIY

\begin{tabular}{|c|c|c|c|c|c|c|c|c|c|}
\hline \multicolumn{2}{|c|}{ Bantul } & \multicolumn{2}{c|}{ Gunungkidul } & \multicolumn{2}{c|}{ Kulonprogo } & \multicolumn{2}{c|}{ Sleman } & \multicolumn{2}{c|}{ Yogyakarta } \\
\hline Code & $\begin{array}{c}\text { Mean } \\
(\mathrm{M})\end{array}$ & Code & $\begin{array}{c}\text { Mean } \\
(\mathrm{M})\end{array}$ & Code & $\begin{array}{c}\text { Mean } \\
(\mathrm{M})\end{array}$ & Code & $\begin{array}{c}\text { Mean } \\
(\mathrm{M})\end{array}$ & Code & $\begin{array}{c}\text { Mean } \\
(\mathrm{M})\end{array}$ \\
\hline DF1 & 3,53 & DF1 & 3,61 & DF1 & 3,55 & DF1 & 3,79 & DF1 & 3,65 \\
\hline DF41 & 2,71 & DF41 & 2,82 & DF41 & 2,76 & DF41 & 2,74 & DF41 & 2,96 \\
\hline DF13 & 2,19 & DF13 & 2,11 & DF13 & 1,97 & DF13 & 2,10 & DF13 & 2,02 \\
\hline
\end{tabular}

\subsection{Traffic Signaling Tools (APILL)}

From Table 4. and Table 5., can be seen that female and male respondents in 4 districts and 1 city have the same opinion in terms of priority sequence regarding traffic signaling tools. They prioritize DF36 "I immediately stop the vehicle when the red light is almost on". Although the mean value is different. They consider DF22 "In my opinion, many of the traffic lights in DIY are blocked by trees / pole / banners / not located in appropriate location" less important.

Table 4. Female respondents opinion about traffic signing tools in 4 districts and 1 city

\begin{tabular}{|c|c|c|c|c|c|c|c|c|c|}
\hline \multicolumn{2}{|c|}{ Bantul } & \multicolumn{2}{c|}{ Gunungkidul } & \multicolumn{2}{c|}{ Kulonprogo } & \multicolumn{2}{c|}{ Sleman } & \multicolumn{2}{c|}{ Yogyakarta } \\
\hline Code & $\begin{array}{c}\text { Mean } \\
(\mathrm{F})\end{array}$ & Code & $\begin{array}{c}\text { Mean } \\
(\mathrm{F})\end{array}$ & Code & $\begin{array}{c}\text { Mean } \\
(\mathrm{F})\end{array}$ & Code & $\begin{array}{c}\text { Mean } \\
(\mathrm{F})\end{array}$ & $\begin{array}{c}\text { Code } \\
(\mathrm{F})\end{array}$ \\
\hline DF36 & 3,03 & DF36 & 3,28 & DF36 & 2,99 & DF36 & 3,51 & DF36 & 3,08 \\
\hline DF14 & 2,81 & DF14 & 2,86 & DF14 & 2,64 & DF14 & 3,25 & DF14 & 2,83 \\
\hline DF22 & 1,95 & DF22 & 2,23 & DF22 & 2,08 & DF22 & 2,26 & DF22 & 2,12 \\
\hline
\end{tabular}

Table 5. Female respondents opinion about traffic signing tools in 4 districts and 1 city

\begin{tabular}{|c|c|c|c|c|c|c|c|c|c|}
\hline \multicolumn{2}{|c|}{ Bantul } & \multicolumn{2}{c|}{ Gunungkidul } & \multicolumn{2}{c|}{ Kulonprogo } & \multicolumn{2}{c|}{ Sleman } & \multicolumn{2}{c|}{ Yogyakarta } \\
\hline Code & $\begin{array}{c}\text { Mean } \\
(\mathrm{M})\end{array}$ & Code & $\begin{array}{c}\text { Mean } \\
(\mathrm{M})\end{array}$ & Code & $\begin{array}{c}\text { Mean } \\
(\mathrm{M})\end{array}$ & Code & $\begin{array}{c}\text { Mean } \\
(\mathrm{M})\end{array}$ & $\begin{array}{c}\text { Code } \\
(\mathrm{M})\end{array}$ \\
\hline DF36 & 3,15 & DF36 & 3,19 & DF36 & 3,11 & DF36 & 3,04 & DF36 & 3,12 \\
\hline DF14 & 2,78 & DF14 & 2,61 & DF14 & 2,76 & DF14 & 2,88 & DF14 & 2,53 \\
\hline DF22 & 2,11 & DF22 & 2,34 & DF22 & 2,13 & DF22 & 2,32 & DF22 & 2,19 \\
\hline
\end{tabular}

\subsection{Completeness of respondents while driving}

Tables 6 and 7 show that women and men in 4 districts \& 1 city prioritize DF15 "I always carry a complete driving documents when I drive car / motor cycle" except for women from Gunungkidul who prefered DF26 "Dysfunction brakes light will always be replaced Quickly ". The least important or lowest ranking according to Bantul women; Sleman and the city of Yogyakarta is DF34 "I think the application of traffic rules in DIY is very good", while the women of Gunung Kidul concerned less with DF35 "In my opinion, the implementation of sanctions against traffic violators in DIY is in accordance with the level and type of violation ", Kulonprogo women are less concerned with being associated with DF33 helmets. For Bantul men; Kulonprogo and Sleman are less prioritizing DF35, while Gunungkidul and Yogyakarta men are less prioritizing DF33 with regard to helmets. 
Table 6. Completeness of female respondents while driving in 4 districts and 1 city

\begin{tabular}{|c|c|c|c|c|c|c|c|c|c|}
\hline \multicolumn{2}{|c|}{ Bantul } & \multicolumn{2}{c|}{ Gunungkidul } & \multicolumn{2}{c|}{ Kulonprogo } & \multicolumn{2}{c|}{ Sleman } & \multicolumn{2}{c|}{ Yogyakarta } \\
\hline Code & $\begin{array}{c}\text { Mean } \\
(\mathrm{F})\end{array}$ & Code & $\begin{array}{c}\text { Mean } \\
(\mathrm{F})\end{array}$ & $\begin{array}{c}\text { Code } \\
\text { (F) }\end{array}$ & $\begin{array}{c}\text { Code } \\
(\mathrm{F})\end{array}$ & $\begin{array}{c}\text { Mean } \\
(\mathrm{F})\end{array}$ \\
\hline DF15 & 3,28 & DF26 & 3,30 & DF15 & 3,37 & DF15 & 3,29 & DF15 & 3,17 \\
\hline DF25 & 3,23 & DF 25 & 3,25 & DF25 & 3,00 & DF26 & 3,17 & DF26 & 3,15 \\
\hline DF26 & 3,15 & DF15 & 3,16 & DF26 & 2,98 & DF25 & 3,12 & DF25 & 2,99 \\
\hline DF21 & 3,07 & DF33 & 3,14 & DF21 & 2,94 & DF21 & 2,83 & DF21 & 2,77 \\
\hline DF33 & 2,70 & DF21 & 3,04 & DF34 & 2,81 & DF33 & 2,72 & DF33 & 2,60 \\
\hline DF35 & 2,61 & DF34 & 2,73 & DF35 & 2,71 & DF35 & 2,61 & DF35 & 2,57 \\
\hline DF34 & 2,58 & DF35 & 2,39 & DF33 & 2,65 & DF34 & 2,54 & DF34 & 2,57 \\
\hline
\end{tabular}

Table 7. Completeness of male respondents while driving in 4 districts and 1 city

\begin{tabular}{|c|c|c|c|c|c|c|c|c|c|}
\hline \multicolumn{2}{|c|}{ Bantul } & \multicolumn{2}{c|}{ Gunungkidul } & \multicolumn{2}{c|}{ Kulonprogo } & \multicolumn{2}{c|}{ Sleman } & \multicolumn{2}{c|}{ Yogyakarta } \\
\hline Code & $\begin{array}{c}\text { Mean } \\
(\mathrm{M})\end{array}$ & Code & $\begin{array}{c}\text { Mean } \\
(\mathrm{M})\end{array}$ & Code & $\begin{array}{c}\text { Mean } \\
(\mathrm{M})\end{array}$ & Code & $\begin{array}{c}\text { Mean } \\
(\mathrm{M})\end{array}$ & Code & $\begin{array}{c}\text { Mean } \\
(\mathrm{M})\end{array}$ \\
\hline DF15 & 3,38 & DF15 & 3,23 & DF15 & 3,35 & DF15 & 3,26 & DF15 & 3,27 \\
\hline DF25 & 3,15 & DF26 & 3,31 & DF25 & 3,10 & DF26 & 3,10 & DF25 & 3,08 \\
\hline DF26 & 3,14 & DF25 & 3,23 & DF21 & 3,09 & DF25 & 3,04 & DF26 & 3,02 \\
\hline DF21 & 2,87 & DF21 & 3,12 & DF26 & 3,09 & DF33 & 2,87 & DF21 & 2,90 \\
\hline DF33 & 2,77 & DF34 & 2,87 & DF34 & 2,95 & DF21 & 2,75 & DF35 & 2,80 \\
\hline DF34 & 2,54 & DF35 & 2,83 & DF33 & 2,69 & DF34 & 2,75 & DF34 & 2,72 \\
\hline DF35 & 2,50 & DF33 & 2,74 & DF35 & 2,63 & DF35 & 2,70 & DF33 & 2,66 \\
\hline
\end{tabular}

\subsection{Attitudes and behavior of respondents about zebra Crossing}

Tables 8 and 9 show that female respondents from all areas of DIY have the same understanding and awareness of DF2 "Pedestrians crossing on the zebra-cross are protected by the Traffic Act". The same thing happened to male respondents. About DF10 which read "Pedestrians feel free to cross anywhere along the way" female respondents of Gunungkidul and Sleman have a high mean, for Bantul and Yogyakarta city close to 3 indicates that, although they are aware and understand the danger and risks, but they dare to do it. This is also the case for male respondents in Sleman with mean result greater than 3. No wonder DF12 " There are differences in difficulty level between crossing in zebra- crossing and not in zebra-crossing" Bantul, Gunungkidul and Sleman are considered by female respondents. Meaningless with the lowest score. For male respondents, DF12 in low mean values is applicable in Gunungkidul and Kulonprogo. There is only a few differences between Women in Kulonprogo and Yogyakarta, they both ignored DF9 "It is difficult to cross the street without the officer's help, even though it's in zebra Crossing". Similarly, DF9 with a low mean value occurs for male in Bantul, Sleman and Yogyakarta. 
Table 8. Female attitudes behavior related with zebra Crossing in 4 districts and 1 city

\begin{tabular}{|c|c|c|c|c|c|c|c|c|c|}
\hline & Bantul & \multicolumn{2}{c|}{ Gunungkidul } & \multicolumn{2}{c|}{ Kulonprogo } & \multicolumn{2}{c|}{ Sleman } & \multicolumn{2}{c|}{ Yogyakarta } \\
\hline Code & $\begin{array}{c}\text { Mean } \\
(\mathrm{F})\end{array}$ & Code & $\begin{array}{c}\text { Mean } \\
(\mathrm{F})\end{array}$ & Code & $\begin{array}{c}\text { Mean } \\
(\mathrm{F})\end{array}$ & $\begin{array}{c}\text { Code } \\
(\mathrm{F})\end{array}$ & $\begin{array}{c}\text { Codean } \\
(\mathrm{F})\end{array}$ \\
\hline DF2 & 3,63 & DF2 & 3,63 & DF2 & 3,56 & DF2 & 4,20 & DF2 & 3,60 \\
\hline DF4 & 3,57 & DF3 & 3,54 & DF3 & 3,51 & DF4 & 4,13 & DF3 & 3,56 \\
\hline DF3 & 3,49 & DF4 & 3,51 & DF4 & 3,36 & DF3 & 4,04 & DF4 & 3,51 \\
\hline DF5 & 3,30 & DF7 & 3,31 & DF7 & 3,01 & DF5 & 3,82 & DF5 & 3,13 \\
\hline DF6 & 3,15 & DF10 & 3,18 & DF5 & 3,00 & DF6 & 3,64 & DF6 & 3,01 \\
\hline DF7 & 3,10 & DF8 & 3,16 & DF6 & 2,92 & DF7 & 3,59 & DF10 & 2,96 \\
\hline DF10 & 2,94 & DF6 & 3,09 & DF8 & 2,83 & DF10 & 3,41 & DF7 & 2,87 \\
\hline DF8 & 2,89 & DF5 & 3,06 & DF10 & 2,70 & DF8 & 3,34 & DF8 & 2,72 \\
\hline DF11 & 2,44 & DF11 & 2,58 & DF11 & 2,18 & DF11 & 2,83 & DF11 & 2,40 \\
\hline DF9 & 1,99 & DF9 & 2,29 & DF12 & 2,12 & DF9 & 2,30 & DF12 & 2,12 \\
\hline DF12 & 1,97 & DF12 & 1,89 & DF9 & 1,95 & DF12 & 2,28 & DF9 & 1,92 \\
\hline
\end{tabular}

Table 9. Male attitudes and behavior related with zebra Crossing in 4 districts and 1 city

\begin{tabular}{|c|c|c|c|c|c|c|c|c|c|}
\hline \multicolumn{2}{|c|}{ Bantul } & \multicolumn{2}{c|}{ Gunungkidul } & \multicolumn{2}{c|}{ Kulonprogo } & \multicolumn{2}{c|}{ Sleman } & \multicolumn{2}{c|}{ Yogyakarta } \\
\hline Code & $\begin{array}{c}\text { Mean } \\
(\mathrm{M})\end{array}$ & Code & $\begin{array}{c}\text { Mean } \\
(\mathrm{M})\end{array}$ & Code & $\begin{array}{c}\text { Mean } \\
(\mathrm{M})\end{array}$ & Code & $\begin{array}{c}\text { Mean } \\
(\mathrm{M})\end{array}$ & $\begin{array}{c}\text { Code } \\
(\mathrm{M})\end{array}$ \\
\hline DF2 & 3,54 & DF2 & 3,64 & DF2 & 3,60 & DF2 & 3,69 & DF2 & 3,49 \\
\hline DF4 & 3,46 & DF3 & 3,63 & DF3 & 3,57 & DF3 & 3,56 & DF3 & 3,48 \\
\hline DF3 & 3,45 & DF4 & 3,51 & DF4 & 3,30 & DF4 & 3,46 & DF4 & 3,33 \\
\hline DF5 & 3,32 & DF5 & 3,20 & DF5 & 2,80 & DF10 & 3,08 & DF5 & 2,99 \\
\hline DF6 & 3,14 & DF6 & 3,14 & DF7 & 2,78 & DF5 & 2,98 & DF6 & 2,80 \\
\hline DF7 & 2,94 & DF7 & 3,13 & DF6 & 2,74 & DF6 & 2,87 & DF7 & 2,78 \\
\hline DF10 & 2,84 & DF8 & 3,09 & DF10 & 2,61 & DF7 & 2,85 & DF10 & 2,75 \\
\hline DF8 & 2,64 & DF10 & 2,81 & DF8 & 2,54 & DF8 & 2,62 & DF8 & 2,68 \\
\hline DF11 & 2,46 & DF11 & 2,29 & DF11 & 2,27 & DF11 & 2,35 & DF11 & 2,23 \\
\hline DF12 & 2,21 & DF9 & 2,26 & DF9 & 2,06 & DF12 & 2,18 & DF12 & 2,06 \\
\hline DF9 & 1,90 & DF12 & 1,83 & DF12 & 1,95 & DF9 & 2,05 & DF9 & 2,02 \\
\hline
\end{tabular}

\subsection{The behavior of respondents while driving.}

For Tables 10 and 11, the highest mean of DF18 is dominated by female respondents from Gunungkidul, Kulonprogo, Sleman and Yogyakarta. The same thing happened also on the part of the male respondent. Both women and men in Bantul prioritize DF37 "During bad weather / rain / misty / smoky, I reduce the speed of the vehicle". For the lowest mean female respondents are Bantul; Kulonprogo and Yogyakarta with DF42 "I always use seat belt while driving.", Gunungkidul with DF43 and DF17 is Sleman. For male respondents, the lowest mean of Bantul and Sleman is DF17 "I overtaking another vehicle either from the left or right side. Whichever easy during traffic jam ", For Gunungkidul; Kulonprogo and Yogyakarta with DF42. 
Table 10. The behavior of female respondents while driving in 4 districts and 1 city

\begin{tabular}{|c|c|c|c|c|c|c|c|c|c|}
\hline \multicolumn{2}{|c|}{ Bantul } & Gunungkidul & \multicolumn{2}{c|}{ Kulonprogo } & \multicolumn{2}{c|}{ Sleman } & \multicolumn{2}{c|}{ Yogyakarta } \\
\hline Code & $\begin{array}{c}\text { Mean } \\
(\mathrm{F})\end{array}$ & Code & $\begin{array}{c}\text { Mean } \\
(\mathrm{F})\end{array}$ & Code & $\begin{array}{c}\text { Mean } \\
(\mathrm{F})\end{array}$ & Code & $\begin{array}{c}\text { Mean } \\
(\mathrm{F})\end{array}$ & $\begin{array}{c}\text { Code } \\
(\mathrm{F})\end{array}$ \\
\hline DF37 & 3,47 & DF18 & 3,90 & DF18 & 3,43 & DF18 & 3,58 & DF18 & 3,41 \\
\hline DF20 & 3,41 & DF38 & 3,48 & DF20 & 3,33 & DF37 & 3,51 & DF45 & 3,24 \\
\hline DF18 & 3,39 & DF20 & 3,40 & DF37 & 3,32 & DF32 & 3,45 & DF38 & 3,23 \\
\hline DF38 & 3,32 & DF37 & 3,38 & DF28 & 3,27 & DF20 & 3,42 & DF37 & 3,23 \\
\hline DF31 & 3,31 & DF28 & 3,36 & DF38 & 3,27 & DF38 & 3,41 & DF31 & 3,19 \\
\hline DF28 & 3,30 & DF31 & 3,33 & DF31 & 3,17 & DF43 & 3,36 & DF20 & 3,16 \\
\hline DF45 & 3,23 & DF45 & 3,33 & DF45 & 3,14 & DF23 & 3,33 & DF28 & 3,12 \\
\hline DF24 & 3,16 & DF24 & 3,31 & DF44 & 3,14 & DF24 & 3,33 & DF32 & 3,12 \\
\hline DF44 & 3,14 & DF32 & 3,18 & DF24 & 3,20 & DF28 & 3,32 & DF44 & 3,07 \\
\hline DF32 & 3,10 & DF23 & 3,10 & DF32 & 3,12 & DF31 & 3,32 & DF24 & 2,97 \\
\hline DF19 & 2,98 & DF40 & 3,09 & DF40 & 2,96 & DF29 & 3,29 & DF29 & 2,97 \\
\hline DF23 & 2,98 & DF29 & 3,03 & DF23 & 2,92 & DF45 & 3,26 & DF23 & 2,85 \\
\hline DF40 & 2,98 & DF19 & 3,00 & DF29 & 2,89 & DF19 & 3,16 & DF27 & 2,85 \\
\hline DF29 & 2,81 & DF27 & 2,90 & DF39 & 2,74 & DF39 & 3,11 & DF19 & 2,79 \\
\hline DF39 & 2,78 & DF44 & 2,86 & DF19 & 2,67 & DF40 & 3,11 & DF39 & 2,77 \\
\hline DF16 & 2,58 & DF16 & 2,79 & DF16 & 2,55 & DF44 & 3,08 & DF40 & 2,77 \\
\hline DF27 & 2,58 & DF39 & 2,79 & DF27 & 2,44 & DF42 & 3,03 & DF16 & 2,73 \\
\hline DF17 & 2,51 & DF17 & 2,66 & DF30 & 2,40 & DF27 & 2,74 & DF17 & 2,33 \\
\hline DF43 & 2,43 & DF30 & 2,49 & DF17 & 2,38 & DF16 & 2,70 & DF30 & 2,24 \\
\hline DF30 & 2,42 & DF42 & 1,76 & DF43 & 0,81 & DF30 & 2,47 & DF43 & 2,19 \\
\hline DF42 & 2,30 & DF43 & 1,75 & DF42 & 0,80 & DF17 & 2,38 & DF42 & 2,04 \\
\hline
\end{tabular}

Table 11. The behavior of male respondents while driving in 4 districts and 1 city

\begin{tabular}{|c|c|c|c|c|c|c|c|c|c|}
\hline \multicolumn{2}{|c|}{ Bantul } & \multicolumn{2}{c|}{ Gunungkidul } & \multicolumn{2}{c|}{ Kulonprogo } & \multicolumn{2}{c|}{ Sleman } & \multicolumn{2}{c|}{ Yogyakarta } \\
\hline Code & $\begin{array}{c}\text { Mean } \\
(\mathrm{M})\end{array}$ & Code & $\begin{array}{c}\text { Mean } \\
(\mathrm{M})\end{array}$ & Code & $\begin{array}{c}\text { Mean } \\
(\mathrm{M})\end{array}$ & Code & $\begin{array}{c}\text { Mean } \\
(\mathrm{M})\end{array}$ & $\begin{array}{c}\text { Code } \\
(\mathrm{M})\end{array}$ \\
\hline DF37 & 3,38 & DF18 & 3,48 & DF18 & 3,54 & DF18 & 3,53 & DF18 & 3,38 \\
\hline DF28 & 3,35 & DF37 & 3,39 & DF20 & 3,50 & DF37 & 3,38 & DF38 & 3,37 \\
\hline DF38 & 3,32 & DF38 & 3,35 & DF38 & 3,34 & DF20 & 3,35 & DF20 & 3,33 \\
\hline DF18 & 3,31 & DF28 & 3,31 & DF37 & 3,33 & DF28 & 3,35 & DF37 & 3,31 \\
\hline DF20 & 3,29 & DF31 & 3,28 & DF28 & 3,30 & DF32 & 3,32 & DF28 & 3,26 \\
\hline DF31 & 3,29 & DF24 & 3,27 & DF44 & 3,30 & DF31 & 3,30 & DF31 & 3,22 \\
\hline DF44 & 3,29 & DF20 & 3,26 & DF31 & 3,29 & DF24 & 3,29 & DF45 & 3,21 \\
\hline DF24 & 3,27 & DF29 & 3,18 & DF45 & 3,24 & DF38 & 3,25 & DF44 & 3,15 \\
\hline DF45 & 3,26 & DF45 & 3,17 & DF32 & 2,94 & DF45 & 3,20 & DF32 & 2,96 \\
\hline DF32 & 3,20 & DF44 & 3,10 & DF23 & 2,91 & DF29 & 3,18 & DF24 & 2,94 \\
\hline DF19 & 3,04 & DF32 & 3,08 & DF24 & 2,84 & DF44 & 3,15 & DF23 & 2,79 \\
\hline DF43 & 3,01 & DF39 & 3,02 & DF40 & 2,84 & DF23 & 3,14 & DF19 & 2,67 \\
\hline DF39 & 2,98 & DF23 & 3,00 & DF29 & 2,71 & DF40 & 3,04 & DF29 & 2,65 \\
\hline DF23 & 2,90 & DF40 & 2,99 & DF39 & 2,60 & DF43 & 3,04 & DF40 & 2,63 \\
\hline DF40 & 2,85 & DF19 & 2,89 & DF27 & 2,33 & DF19 & 2,96 & DF39 & 2,57 \\
\hline DF29 & 2,77 & DF27 & 2,70 & DF19 & 2,27 & DF39 & 2,88 & DF27 & 2,56 \\
\hline DF42 & 2,77 & DF16 & 2,65 & DF30 & 2,27 & DF42 & 2,80 & DF30 & 2,35 \\
\hline DF27 & 2,76 & DF30 & 2,43 & DF16 & 2,25 & DF27 & 2,69 & DF43 & 2,31 \\
\hline
\end{tabular}




\begin{tabular}{|c|c|c|c|c|c|c|c|c|c|}
\hline DF30 & 2,55 & DF17 & 2,33 & DF17 & 2,09 & DF30 & 2,50 & DF17 & 2,23 \\
\hline DF16 & 2,47 & DF43 & 0,99 & DF43 & 2,07 & DF16 & 2,46 & DF16 & 2,10 \\
\hline DF17 & 2,43 & DF42 & 0,95 & DF42 & 1,91 & DF17 & 2,27 & DF42 & 2,07 \\
\hline
\end{tabular}

\section{Conclusion}

The results of the analysis can be summarized as follows: a) For female and male respondents in 4 districts and 1 city have the same understanding about traffic sign and also APILL, b) men and women in all areas of Yogyakarta except women in Gunungkidul understand and realize the importance of carrying complete documents while driving, c) Although people in DIY, both men and women, understand and realize the importance of APILL and that crossing the road through the zebra Crossing protected by law, they still assume that people can cross anywhere anyway. d) all men and women in DIY (except male and female respondents from Bantul) give priority to the sign when they want to turn and move to another lane, while Bantul respondents prefer to reduce the speed of vehicle during bad weather / rain / fog. e) the highest mean of DF18 "When I want to turn or change lanes, I always turn on the turn signal lights" is dominated by female respondents from Gunungkidul, Kulonprogo, Sleman and Yogyakarta, while both women and men in Bantul prioritize DF37 "During bad weather / rain / misty / smoky, I reduce the speed of the vehicle".

\section{References}

1. Anonim, Undang-undang Republik Indonesia No. 22 tentang Lalu lintas dan Angkutan jalan (2009)

2. H. Ch. Heinrich, IATSS, 14 No 1, 85 (Tokyo, 1990)

3. M. Fishbein, I. Ajzen, Predicting And Changing Behavior, 87 (Psychology Press, Routledge, 2015)

4. P. E. Purnamasari, D. Ansusanto, E-Journal. Uajy (2016) 